This was published as:

Corbett, C. (2008) 'Roads policing: current context and imminent dangers'. Policing:

A Journal of Policy and Practice, 2(1):131-142; doi:10.1093/police/pam071

\title{
ROADS POLICING: CURRENT CONTEXT AND IMMINENT DANGERS
}

\begin{abstract}
This paper will argue that roads policing is the public face of the police for many citizens and thus enjoys an elevated profile. Yet the delivery of roads policing services requires urgent care and attention. As was the situation a century ago, potential and actual conflict with the driving public could be close at hand as more reliance is placed on enforcement technology and more drivers become criminalised and their vehicle movements logged. Indeed, it will be contended that unless great care is taken, such could be the public disaffection with traffic law enforcement and monitoring policies that the legitimacy of the police itself could be challenged. After a brief update of recent developments concerning roads policing nationally and internationally, the second section will underline the ways in which roads policing provides a crucial service. Details follow of dangers lying in wait for the service if the pressing enforcement issues around roads policing are allowed to drift. Finally, some suggestions are outlined to help inform discussion of these matters that could simultaneously facilitate achievement of other key roads policing objectives.
\end{abstract}

\section{An elevated public profile}

The roads arguably represent the public space shared and used most commonly by the population as pedestrians, cyclists, passengers and drivers. Roads facilitate our mobility and underpin the smooth functioning of our lives, evidenced by the chaos that can arise from road closures. Understandably, ordinary users wish to feel reassured of their safety and security when using the roads and that compliance with the road laws is enforced. For this they are most likely to look to the roads police. So by default roads policing enjoys an elevated profile among the public, and one might contend that for many it is the public face of the police.

This is the case not only for road users ordinarily, but also when they come within the purview of roads police as victims of road crashes or road crime, and as road traffic offenders. Indeed, it still holds that in Britain the most common means of policeinitiated contact with citizens is in the context of a vehicle stop (e.g. Skogan, 1990: 27-28; Allen et al, 2005: Table 2.04), and in 2003-04 this was the second most common context for any police-public contact (ibid).

This is likely to have been true even at the advent of the motor-car when those who could afford them - the elite and the affluent - were often brought into unaccustomed and unwelcome contact with the police over the vexed issue, then as now, of speed limit breaches (e.g. Corbett, 2003: 16-18). In the 1920s, this caused the issue of speeding prosecutions to be aired in the Houses of Parliament and addressed by the Home Secretary (Emsley, 1993: 374-376). This is not unimaginable today as militancy among a minority and disaffection and concern among a growing proportion of other citizens becomes apparent through a proliferation of websites, 
blogs, a national petition and online surveys on road issues wider than but including speeding.

An obvious change since the 1920s is that proportionately more contacts with drivers and vehicle owners occur via the post with the arrival of a Notice of Intended Prosecution (NIP) initiated by automated camera enforcement than by a police stop. Another is that few people owned, drove or rode in any motorised vehicle then, so any grievances affected a small minority. In the new millennium, $75 \%$ of households in Great Britain have access to at least one car (DfT, 2006: 8) and 72\% adults hold a full driving licence (ibid: Table 2.3: 11), so the dangers to police and government of widespread disaffection should be clear.

\section{Current context of Roads Policing}

The centrality of the roads ensures the high importance of roads policing for road users, but this has not necessarily been the case from the perspective of government or police. HMIC noted in 1988 (p. 12) the marginalisation of roads policing among local forces, and while the government's response to the Transport Select Committee's (TSC) 2006 report on roads policing affirms that roads policing plays a core role in policing, it also notes that this is just one of 27 types of policing and that it cannot be the only concern of police (HoC Transport Committee, 2007: 5). This is hardly a ringing endorsement for roads policing activities. Moreover, the latest 2005-08 National Policing Plan (Home Office, 2004a) makes scant mention of roads policing, which may link with the concern of the TSC that not all forces have adopted the latest Roads Policing Strategy (HoC Transport Committee, 2007: 7).

Gaventa, on behalf of the Parliamentary Advisory Council for Transport Safety, points out (2005: 15) that roads policing in the 2004-07 National Policing Plan was reduced to 'an example of the key priority to 'reduce people's concerns about crime, and anti-social behaviour and disorder' [italics added] rather than being seen as a separate area of work in its own right. In addition to the long-term decline in specialist traffic officer numbers (e.g. HMIC 1988: 11; Hansard, 20.12.05, Col. 2905W and 11.11.05, Col. 853W; Gaventa, 2005: 11-13), the transfer in 2002 of traffic officers to street crime duties under the Safer Streets initiative in the ten forces with greatest need (Loveday and Reid, 2003: 28), illustrates how dispensable such officers have become.

The government is also keeping a fairly low profile on the European stage with regard to roads policing. Several issues have emerged in recent years whereby European harmonisation on standards or regulations is being sought, and while Britain is not alone in reluctance to comply or in stalling for more time, there are indications that achieving European consensus is not its primary concern, e.g. in relation to drinkdrive limits and day-time running lights. The next test could arrive in the shape of a European-wide Directive for member states to observe best enforcement practice of the 'big three' offences of speeding, drink-driving and seat-belt use (ETSC, 2007).

The context for such a Directive was an annual road fatality rate of 40,000 casualties in 2001 that the European Union has a target to halve by 2010, and a growing problem of high offending and crash levels among non-resident drivers using roads in other member states (ETSC, 2007: 7). Research commissioned by the EU estimated 
that up to 14,000 European lives would be saved annually through best enforcement standards for the three offence categories above (ICF, 2003). Current progress from a recent consultation (EC, 2006a)) indicates the target may not be attained, and this possibility had prompted the EU earlier in 2004 to reserve the right for binding legislation in the form of a Directive should this look likely. The European Transport Safety Council representing 37 European national and international bodies, supported by the European Traffic Police Network (TISPOL), is leading the call for such a Directive (ETSC, 2007), though whether the political will of individual member states would suffice to ensure a true European-wide consensus to enforce these three offence groups appropriately, remains to be seen.

Returning to the British context, on the plus side a core roads policing performance indicator has recently been devised. This is SPI 9a (HMIC, 2005) concerning the reduction of road casualties, and it complements the government's broader road safety objective to reduce Killed and Seriously Injured (KSI) casualties by $40 \%$ over the decade to 2010, compared with the baseline average for 1994-98 (DETR, 2000: 7). It also chimes with the European target above. With the impetus of this target for all police forces, headway may finally be made in raising the profile of roads policing among police at all levels.

Certainly, a range of civilian agencies and support staff have been introduced to assist sworn officers in their roads policing duties and to free up their time for the core enforcement task. This is in line with the extended policing family model (Home Office, 2004). The Highways Agency supplies traffic officers (HATOs) to manage and monitor traffic flow on the roads network and at collision sites; the Vehicle Operator Services Agency (VOSA) conducts compliance checks especially of commercial and foreign vehicles; Police Community Support Officers (PCSOs) have powers under the Serious Organised Crime and Police Act (SOCPA) 2005 to direct traffic; Special Constables also have a support role to roads police officers, and local authority and police traffic wardens can enforce decriminalised offences like parking, junction box and bus lane breaches.

Other new agencies assisting the roads police are the Vehicle Crime Intelligence Service, and the Vehicle Surveillance Police Agency. Along with additional development funds for Automatic Number Plate Recognition (ANPR) from government (over $£ 35 \mathrm{~m}$ in 2006), it appears that various features of roads policing are being considered more seriously at the centre, especially the issue of who should do it.

The net effect of all recent and contemporary developments is that a somewhat mixed message has emerged with government facilitating some aspects but seeming reticent about wholehearted endorsement of roads policing activities. It may not be surprising therefore if some ambivalence at management level should occur in individual forces as to how far roads policing should be prioritised. The following points that feed into its five core elements (ACPO/DfT/Home Office, 2005: 1-2) should help apprise waverers of its vital roles and consequent worth.

\section{How Roads Policing is vital:}

Denying criminals the use of the roads 
The current roads policing objective to deny criminals use of the roads is bolstered by research that shows a high cross-over between minor and major traffic offending, and offending on the road and mainstream crime. So for example, Rose (2000) found that convicted drink-drivers were twice as likely, and disqualified or dangerous drivers four times as likely as the general population to have a criminal record for mainstream offending. The classic 'own goal' study of Chenery, Henshaw and Pease (1999) highlights this tendency whereby those who parked illegally in parking bays were much more likely to 'be of interest to, or wanted by, police' than those parked legally in adjacent bays. And Broughton (2006: Table 5), using a very large sample, showed that drivers with a poor motoring offence record tended to commit many more nonmotoring offences than those who committed no motoring offences.

Together these studies illustrate how investment in roads policing could make a big difference to intelligence-led targeting of serious mainstream offenders and suspects and that the continuing Government investment in ANPR is well directed. The contribution that can be made by ANPR is particularly relevant in regard to the growing problem of 'fail to stop' collisions, whereby estimates suggest a 'large' proportion of such offenders are young men who drive without adequate insurance, tax, driver licence or vehicle registration (MPS/TfL, 2006), all of which can be readily picked up by ANPR activity.

\section{Casualty reduction}

Killed and seriously injured casualties on the road represent a far larger problem in sheer numbers than homicides occurring off the road, with more than four times as many people killed on British roads in 2004 as were recorded homicide victims. ${ }^{\text {i }}$ Yet it is probable that more resources are made available to investigate homicides by unknown perpetrators than the drivers of 'fail to stop' fatal collisions.

Road deaths have become the biggest killer of 10-24 year olds worldwide with more than 1000 under 25s killed on the roads daily (WHO, 2007), and road deaths are estimated to become the world's third biggest killer overall by 2020 (Jacobs et al, 2000). In this country, the $50 \%$ KSI reduction target for child casualties set by government is well on course to be achieved by 2010, yet child road deaths still rose $20 \%$ in 2006 from the previous year, showing that complacency must be avoided (DfT, 2007).

Roads policing can help make a vital contribution to casualty reduction by providing a visible deterrent against bad driving offences like dangerous, drunk, and drugged driving, by driver education including giving informal and formal warnings, and by continued ANPR use to detect some kinds of driver with a raised crash risk, such as those with inadequate documentation.

Tackling the threat of terrorism

In the run-up to the London Olympics in 2012, the involvement of roads traffic police in counter-terrorist operations and monitoring will take on an increasingly crucial role. The recognition that many criminals use roads to get to and flee their crime destinations underlines the importance of roads policing, and of how through the targeted intelligence use of ANPR, roads policing can significantly contribute to counter-terrorism surveillance. 


\section{Reducing anti-social use of the roads}

When communities have been consulted on traffic enforcement for Crime and Disorder Reduction Partnership audits, they place road safety high in their list of policing priorities (Manning: 1999:1, cited in Gaventa, 2005:16), and their corresponding local authorities are far more likely to produce a road safety strategy than authorities who do not ask about this (ibid). More recently, Wood (2004:11) showed that $43 \%$ of the population regarded speeding traffic as a 'fairly' or 'very big problem' in their local area, and this was the most commonly mentioned community concern about anti-social behaviour. Speed cameras are still rarely installed away from main roads and so are unlikely to detect those using excess or inappropriate speed on residential estates, and as expansions in roadside CCTV installations show equivocal results in terms of increasing the public's feelings of safety (Ditton, 2000), something more is needed from roads policing.

Enhancing public confidence and reassurance by patrolling the roads Recent Home Office commissioned research confirms the findings of opinion surveys that the public want more visibility of the police and more engagement with them (e.g. Innes, 2006, 14-15 ; Tuffin et al, 2006). These wishes are seen in current police objectives (ACPO, 2001), encapsulated by reassurance programmes aimed at enhancing the public's feelings of safety and confidence in the police. Reassurance is also a core element of roads policing, as noted.

Low visibility of motorised patrols is a likely key reason why drivers continue to exceed limits away from fixed camera sites, and why the trend for drink driving fatalities is up since 1998 (DfT, 2006: Table 2a) while that for breath tests undertaken is down since 1998 (Home Office, 2006: Table 18). Many drivers may be prepared to gamble in the face of low perceived risk of detection by a passing police patrol car (e.g. Corbett et al, 1991; Corbett, 2003: 84). Moreover, illegal behaviours such as dangerous driving and drink and drug driving are not yet enforceable by camera technology and are reliant on police patrols for detection. So leaving too much to the enforcement capabilities of technology could backfire with road traffic offenders feeling reassured and compliant drivers questioning the usefulness and efficacy of the police.

Conversely, given the increasing numbers of registered vehicles (DfT, 2006: Table 9.1) and total vehicle distances travelled (ibid: Table 7.1), the use of enforcement technology that works $24 / 7$ looks set to stay and it is unrealistic simply to call for more randomly deployed patrols using sworn officers, whether specialist traffic officers or not. This will be taken up in the conclusion.

The future of roads policing therefore looks techno-tinged, if not techno-coloured whatever the deployment level of road patrols, though various dangers lie in wait for the continued deployment of enforcement technology.

\section{Troubles ahead?}

\section{Camera technology and creeping criminalisation}

Speed cameras were originally introduced to encourage compliance with speed limits in order to reduce road casualties, and where installed, cameras have achieved this objective (e.g. Pilkington and Kinra, 2005). In Britain too, annual evaluations have 
shown that cameras do reduce casualties (Gains et al, 2005: 2), even taking into account regression-to-mean effects (ibid: 154-158). This means their net effectiveness is somewhat lower than some figures suggest, but very worthwhile achievements in saving lives result. Despite this, not all are happy with speed camera technology and care will be needed to maintain current levels of support and keep driver dissatisfaction in check.

Drivers tend to believe their driving is above average (e.g. Svenson, 1981; Gregersen, (1996). It is thus an affront to their good judgement when speed cameras tell them their speed choice was wrong, particularly when some speed limits are determined by local authorities (e.g. Directgov, 2007).

It may also aggravate that they see themselves as 'sitting ducks', being fully paid-up and easily located members of the motorised fraternity, while the 'motoring underclass' (RAC Foundation, 2007) who choose not to register their vehicles, readily escape detection and sanction. Such aggrieved drivers may perceive that their honesty for complying with driving requirements is penalised, and that they represent 'easy money' for the authorities when penalty points and fixed penalty notices follow. Indeed, in London reportedly 'less than half get the points they should be awarded' through being untraceable (Radio 4, 2007).

Camera expansion has signalled an increase in speeding offences detected by camera and dealt with by fixed penalty notices or prosecutions from 207,000 in 1995 (Home Office, 1996: Table D) to 1,914,000 in 2004 (Home Office, 2006: Table D). At the same time, camera enforcement has largely taken over from police patrol enforcement in the detection of all speeding offences, e.g. from 30\% in 1995 (Home Office, 1996: 9-10) to $88 \%$ in 2004, Home Office, 2006: 14). Current estimates from a survey of a representative sample of 2,291 British adults suggest that around $16 \%$ of motorists have penalty points on their driver licences (most of them likely to have 3 points), around $85 \%$ of such points are for speeding, and the proportion at risk of disqualification at next motoring conviction is rising annually (Direct Line Insurance, 2007).

Thus while some drivers will have previous convictions for mainstream offences, it also appears probable that a growing proportion of fully licensed drivers are being criminalised through points for speeding. This could become more common in future as more time/distance 'average speed' SPECS cameras take the place of, or supplement, traditional GATSO and Truvelo speed cameras, since those drivers who exceed limits between the sites should no longer escape detection.

For those with no previous criminal record, first penalty points could cause them critical self-reflection as 'tainted', 'sullied', no longer able to think of oneself as lawabiding, or from another perspective, they could cause feelings of anger with, or lost confidence in, the police's judgement, or an experience of alienation from them. This underlines the care that could be needed to keep 'onside' those who may feel criminalised or disaffected by camera technology. Clearly, it would be politically injudicious to criminalise the majority of voters and erode what has been majority public support for cameras since their inception (e.g. Gains et al, 2005: 1). 
Driver grievances of this kind may underpin and help explain the huge outpouring of public support in 2007 to sign the Downing Street petition registering disapproval of road pricing schemes (10 Downing Street website, 2007) that may be introduced to discourage and rebalance use of Britain's congested roads. Certainly similar issues are at root such as legitimately registered drivers perceiving themselves as 'easy pickings' unable to avoid the charges while the 'invisible' unregistered and unlicensed remain untraceable. Moreover, pricing schemes, similarly to speed cameras, are likely to be viewed as a revenue generating tool.

\section{ANPR and discretion}

Recent evaluations show this is an extremely efficient and cost-effective means of enforcement (e.g. MPA, 2005), as it largely takes the guesswork out of police intercepts to produce a reportedly nine-times higher arrest rate than achieved by routine patrols (e.g. PA Consulting, 2004: 1).

A key plus point for this technology is that discretion is very largely removed from officers in deciding which individuals to stop, so that any potential discrimination in targeting certain individuals seen as high risk - as is often claimed for street stop and searches (see Waddington, Stenson and Don (2004) - is also removed. However, the careful planning needed to deploy ANPR operations may often understandably concentrate on high volume crime areas (e.g. MPS/TfL (2006: 7-9). Yet focusing ANPR efforts on specific districts raises the likelihood that particular risk groups will be over-represented that could prove awkward for police in the post-MacPherson era. This happened in 2006 when several minority ethnic groups were considerably overrepresented among drivers arrested following stops using ANPR compared to their proportions in the national population (ibid: 34-35). Naturally, police and the authorities are sensitive to this issue and careful monitoring will be needed by police to ensure such operations are perceived as fair by local communities and the wider public.

Long-term storage of locator data, privacy intrusion and the potential leakage of data It is reported in the ACPO's ANPR strategy for the Police Service 2005-08 that the National ANPR Data Centre anticipates the retention of data from 50 million daily number plate 'reads' by 2008 (ACPO, 2005: 8). These data will be gathered via a network of thousands of closed-circuit cameras on main roads, town centres, garage forecourts and other roads linked to many key databases for monitoring checks. Further, these vehicle sighting records can be digitally stored for 2 years with the potential capacity for storage up to 5 years (ibid: 14, 17). Thus the journeys of any and all drivers could be revisited by police retrospectively for a considerable period, and, according to ACPO, developments with this technology 'will revolutionise arrest, intelligence and crime investigation opportunities on a national basis' (ibid: 18).

ANPR technology could become as ubiquitous as speed camera and traffic signal technology, but unlike data being retained only from transgressing vehicles detected in flagrante delicto, ANPR data storage will also comprise time and place observations of vehicles of 'no current interest' or 'no previous police interest' but that may become so in future. This may be useful for future intelligence purposes, and to date the public have largely supported CCTV technology (e.g. Gains et al, 2005; Corbett and Simon, 1999). Yet it may stretch the public's tolerance should 
there be widespread monitoring and long-term storage of vehicles that are legitimately going about their business, especially if such data are retained along with the details of the registered owner, and likely or actual drivers.

Other technologies capable of recording vehicle sightings are waiting in the wings for a roll-out and similar concerns might apply to their potential capacity for long-term data storage. These include Intelligent Speed Adaptation (ISA) that would use satellite technology to restrict vehicles' speed to the permitted maximum along the highway by linking an in-vehicle electronic device to roadside sensors; the so-called 'black boxes' or e-Call that would automatically alert emergency services to a crash location via GPS co-ordinates that would be mandatorily fitted to new vehicles by 2009 if Britain complies with an EU request (EC, 2006b); and road pricing schemes that are likely to use similar GPS technology to monitor vehicles as they pass roadside sensors. What these technologies represent is a potentially huge incursion into the privacy of legitimate drivers, and a crucial issue will be the extent to which drivers can opt out from using such schemes in the future.

Moreover, there is a capacity for abuse with stored locator data being accessed or 'sold on' at a later point by state or commercial agencies for tracking, intelligence, commercial or corrupt purposes (e.g. Lyon, 2001: 45), which scenario may not be too far-fetched given that corruption within commercial and state organisations and the police service is not unknown (e.g. The Information Commissioner's Office, 2006: 15-16). Already it appears that the British government has exempted Transport for London (the transport authority for the capital) from certain Data Protection Act 1998 provisions. This will allow bulk data collected by its ANPR cameras linked to London's congestion charge to be viewed in 'real-time' by the MPS' anti-terrorist officers (BBC News, 2007). This intelligence-sharing may be beneficial for the police service's fight against terrorism and all crime but the potential for unauthorised leakage exists, and public tolerance could wane considerably should this happen.

\section{Suggestions}

As has been contended here, roads policing is the face of the police for many people especially the travelling public, a point noted by Southgate and Mirrlees-Black (1991: 5), where among the forces studied, the traffic branch was often seen as the 'flagship'. Given its prominence, the centrality of the roads in many contemporary lives and the tensions around roads policing outlined, extreme care is needed to prevent the mounting rumblings of disquiet turning into a louder and broader clamour as occurred among the elite a century ago. Several suggestions to inform the debate follow.

\section{Choice to stay within the speed limits}

Part of the anger of drivers detected for speeding can stem from the offence being inadvertent through temporary inattention or through failing to realise a change in the speed limit or believing it to be higher (e.g. Corbett and Simon, 1999: 37-8).

Although ISA is ready for roll-out even if mandatory usage mode may be a while away, Britain could perhaps follow international examples whereby new vehicles are fitted with cruise controls as standard for voluntary usage to help prevent inadvertent excess speed - though this does not work where the correct posted maximum is unknown. It seems important for drivers to have a means to stay within speed limits at all times if they wish to do this to prevent further 'creeping criminalisation' and the 
possibility of mass driver disaffection. ${ }^{\text {ii }}$ This is not to deny drivers their individual responsibility for choice of speed, but it does acknowledge that some instances of speeding are unintended and that many disgruntled individuals make a large mass.

Plugging gaps in vehicle document and driver licence systems

Other grievances connected with speed cameras could transfer to road charging schemes if introduced. These involve the perception of being easy targets as fully 'paid-up' legitimate members of the driving community, who are readily identifiable for red light and speeding breaches while the 'real criminals' escape detection. This is not a good police-community relations strategy, so urgent attention by government with help of the police is needed to plug gaps in the vehicle registration, insurance, excise licence and driver licence systems and procedures. This includes the fraudulent use of driver licences arising through loopholes in driving test procedures and of car number plates.

\section{Safeguards for the storage of surveillance data}

The Information Commissioner has warned that the country risks 'sleepwalking into a surveillance society’ (e.g. The Times On-Line, 16.8.04), so it is hoped that senior police, especially senior roads police, will be well prepared for potential negative fallout if and when the public 'wake up' either to concerns about the adequacy of safeguards in place against leakage of any stored vehicle and driver data maintained directly or indirectly by police, or to any seepage itself. There might be issues of liability for police if secure operation of any of these systems that conjoin or blur commercial and police enterprise, such as tracker systems, were compromised. Moreover, the Chief Surveillance Commissioner has warned that until legislation makes data gathered by ANPR compliant with privacy laws, the use of covert surveillance by ANPR might be challenged in court under human rights and privacy legislation (Office of Surveillance Commissioners, 2006:18).

\section{ANPR education}

In the meantime, the public may yet be unaware of what visible intercept ANPR teams are actually doing and can achieve. For the purposes of public and driver education and reassurance, it would be desirable therefore to stress in publicity campaigns the known links between those convicted of document offences and their raised crash and offending risks (e.g. Blows et al, 2003; Greenaway, 2004) and the extent of ANPR successes.

Extending visible patrols through the extended police family Patrolling the roads is a key objective for public reassurance, and recent surveys suggest the public want more such patrols e.g. (Innes, 2006: 14). Patrols yield further benefits. Visible motorised patrols signal to the public that compliance with traffic laws is being monitored and that would-be and actual offenders are being deterred and detected. Less frequent bad driving not amenable to automated enforcement should ensue through detection and deterrence. This should lead to fewer road casualties, less anti-social use of the roads, and perhaps fewer criminals using the roads, or if so with a higher risk of detection. Even terrorist activity could be at higher detection risk if more roads monitoring happened.

Yet sworn officers are a limited resource and too valuable to use on random patrols especially with even greater financial constraints ahead, so has the time come to 
confer more powers to detain and to arrest upon the extended police family? HATOs could provide visible patrol coverage of the motorways as a Highways Police agency; PCSOs and special constables could be deployed for visible motorised urban patrols, while sworn officers would continue with intelligence-led patrols. Not only would deterrence of road offenders increase; the public's perception of safety on the roads might also. Moreover, there could be a knock-on effect of a lowered fear of (roads) crime and heightened positive quality of life feelings. In a review of road policing enforcement studies, Elliott and Broughton (2004: 1) concluded inter alia that highly visible, random patrols over the whole road network were the most likely type to increase deterrence, particularly stationary deployment. Use of the extended police family in this reassurance endeavour would not only represent a less costly means of meeting public concerns, but would simultaneously help realise the other key objectives of roads policing that would have benefits for the public and the police service as a whole.

\section{Conclusion}

Roads policing provides a crucial service but requires urgent care and attention. Future road law enforcement policy and practice will inevitably be driven by technology, and potential problems associated with this cannot be ignored. To allow the imminent dangers discussed here to drift unresolved could augur badly for police in general, with disaffection or lowered confidence in the police among the mass of drivers leading to a public backlash culminating in an eventual challenge to the legitimacy of the police service itself. There is still time, though delay is not an option.

\section{References:}

Allen, J., Komy, M., Lovbakke, J. and Roy, H. (2005) Policing and the Criminal Justice System - Public Confidence and Perceptions: Findings from the 2003/04 British Crime Survey. Home Office Online Report 31/05. http://www.homeoffice.gov.uk/rds/pdfs05/rdsolr3105.pdf

Association of Chief Police Officers (ACPO) (2001) Blueprint for Policing in the $21^{\text {st }}$ Century. http://www.acpo.police.uk/asp/policies/data/blueprnt.doc

ACPO (2005) ANPR Strategy for the Police Service 2005-08.

http://www.acpo;.police.uk/asp/policies/Data/anpr_strat_2005-

08_march05_12x04x05.doc

ACPO/Department for Transport/Home Office (2005) Roads Policing Strategy. London: ACPO/DfT/Home Office. http://www.acpo.police.uk/asp/policies/data/acp_dft_ho_rp_strat_jan05.pdf BBC News BBC News (2007) 'Met Given Real Time C-Charge Data'. 17.07.07. http://news.bbc.co.uk/go/prfr/-/1/hi/uk_politics/6902543.stm

Blows, S., Ivers, R, Connor, J., Ameratunga, S and Norton, R. (2003) 'Car Insurance and the Risk of Car Crash Injury'. Accident Analyis and Prevention, 35: 987-990. Broughton, J. (2006) 'The Correlation between Motoring and Other Types of Offence’. Accident Analysis and Prevention. DOI: 10.10.16/j.aap.2006.07.006. Chenery, S., Henshaw, C. and Pease, K. (1999) Illegal Parking In Disabled Bays: A Means Of Offender Targeting. Briefing Note 1/99, HORS. London: Home Office. 
Corbett, C., Simon, F. And Hyde, G. (1991) 'Driving With Excess Alcohol: Why Some Drivers Do And Why Some Don't’. In Behavioural Research In Road Safety: II, 108-117, (Eds. G. Grayson And J. Lester). Crowthorne: TRRL.

Corbett, C. And Simon, F. (1999) The Effects Of Speed Cameras: How Drivers

Respond. Road Safety Research Report 11. London: DETR.

Corbett, C. (2003) Car Crime. Cullompton: Willan Publishing.

Cox, S. (2007) The Investigation. 19.4.07. London: BBC, Radio 4.

DETR (2000) Tomorrow's Roads: Safer For Everyone. London: DETR.

Dft (2006a) National Travel Survey 2005. London: Dft.

http://www.dft.gov.uk/pgr/statistics/datatablespublications/personal/mainresults/nts20

05/nationaltravelsurvey2005

Dft (2006b) Transport Statistics Great Britain 2006. London: Dft.

Dft (2007) Transport Statistics Bulletin: Road Casualties In Great Britain. Main

Results 2006. London: Dft.

Direct Line Insurance (2007) 'One Million Brits Close To Driving Ban’, 29.3.07

http://www.directline.com/about_us/news_290307.htm

Directgov (2007) 'Speed Limits - How They Are Set'.

http://www.direct.gov.uk/en/homeandcommunity/whereyoulive/streetsparkingcleanin gandlighting/dg_10028438

Ditton, J. (2000) 'Crime And The City: Public Attitudes To CCTV In Glasgow'.

British Journal Of Criminology, 40, 692-709.

10 Downing Street Website (2007) E-Petition to scrap the planned vehicle tracking

and road pricing policy. http://petitions.pm.gov.uk/list/closed?cat=521

EC (European Commission) (2006a) Respecting The Rules: Better Road Safety

Enforcement In The European Union.

http://ec.europa.eu/transport/roadsafety_library/consultations/consultation_paper_enfo rcement_20060411.pdf

EC (2006b) 'EU: Ecall - European Parliament Calls For Automatic Accident Alert

Service For Europe’s Roads’. 15.5.06. http://ec.europa.eu/idabc/en/document/5564

Elliott, M. And Broughton, J. (2004) How Methods And Levels Of Policing Affect

Road Casualty Rates. TRL Project Report PR SE/924/04. London: Transport For

London.

Emsley, C. (1993) “"Mother, What Did Policemen Do When There Weren’t Any Motors?" The Law, The Police And The Regulation Of Motor Traffic In England, 1900-1939'. The Historical Journal, 36(2), 357-381.

ETSC (European Transport Safety Council) (2007) 'Enforcement In The EU - Time

For A Directive’. http://www.etsc.be/documents/ets\%20001-07.pdf

Gains, A., Nordstrom, M., Heydecker, B. And Shrewsbury, J. (2005) The National

Safety Camera Programme: Four Year Evaluation Report. London: Department Of

Transport.

Gaventa, J. (2005) Policing Road Risk: Enforcement, Technologies And Road Safety.

London: Parliamentary Advisory Council For Transport Safety.

Greenaway, D. (2004) Uninsured Driving In The UK. London: Dft.

HMIC (1998) Road Policing And Traffic: HMIC Thematic Inspection Report.

London: Home Office.

Gregersen, N. (1996) 'Young Drivers' Overestimation Of Their Own Skill - An

Experiment On The Relation Between Training Strategy And Skill.' Accident

Analysis And Prevention, 28(2), 243-250.

HMIC (2005) HMIC Baseline Assessment Framework Specific Grading Criteria, No. 5 . 
http://inspectorates.homeoffice.gov.uk/hmic/docs/5c.pdf?view=binary

Home Office (1996) Motoring Offences: England And Wales 1995. Statistical Bulletin. 24/96. London: Home Office.

Home Office (2004a) National Policing Plan 2005-08: Safer, Stronger Communities. London: Home Office Communications Directorate.

Home Office (2004b) Building Communities, Beating Crime: A Better Police Service For The $21^{\text {st }}$ Century. Cmd 6360. London: HMSO.

Home Office (2006) Motoring Offences And Breath Test Statistics: England And Wales 2004. 05/06. London: Home Office.

House Of Commons Transport Committee (2007) Roads Policing And Technology:

Getting The Right Balance: Government Response To The Committee's Tenth Report Of Session 2005-06. HC 290. London: TSOL.

ICF Consulting (2003) Cost Benefit Analysis Of Road Safety Improvements: Final Report. London: ICF.

Information Commissioner's Office (2006) What Price Privacy? The Unlawful Trade in Confidential Personal Information. HC 1056. London: The Stationery Office.

Innes, (2006) 'The Public Face Of Policing’. Criminal Justice Matters, 63: 14-15. Jacobs, G., Aeron-Thomas, A. And Astrop, A. (2000) Estimating Global Road Fatalities. TRL Report 445. Crowthorne: TRL.

Loveday, B., And Reid, A. (2003) Going Local: Who Should Run Britain's Police? London: Policy Exchange.

Lyon, D. (2001) Surveillance Society: Monitoring Everyday Life'. Buckingham: Open University Press.

Manning, P. (1999) ‘Crime And Disorder Strategies - Local Responses’. Letter To David Kidney MP, 27.7.99. London: ACPO Traffic Committee.

Metropolitan Police Authority (2005) Automatic Number Plate Recognition Activity Update Report.

http://www.mpa.gov.uk/committees/cop/2005/051202/05.htm?qs=1\&qu=automatic + n umber + plate + recognition $\& n h=\& m c=3 \& s c=1 \& s=1 \& a r=\& p o=\& f o=\& l v=\& d t=0 \& s 0=2$ \&pg $=3 \& h \mathrm{l}=1$

Metropolitan Police Service/Transport For London (2006) Evaluation Of Operation FOIST. London: MPS/Tfl Strategic Research Unit.

Office Of Surveillance Commissioners (2006) Annual Report For 2005-2006.

HC1298. SE/2006/95.

http://www.surveillancecommissioners.gov.uk/docs1/annualreport200506.pdf

PA Consulting (2004) Driving Crime Down: Denying Criminals The Use Of The Road. London: PA Consulting/ACPO/Home Office.

Pilkington, P. And Kinra, S. (2005) 'Effectiveness Of Speed Cameras In Preventing

Road Traffic Collisions And Related Casualties: Systematic Review.' BMJ.Com:

330: 331-334. http://bmj.com/cgi/doi/10.1136.bmj.38324.646574.ae

RAC Foundation (2003) 'Crime And Punishment'. News Release, 8.12.03.

http://www.racfoundation.org/index.php?option=com_content\&task=view\&id=87\&it emid=35

Rose, G. (2000) The Criminal Histories Of Serious Traffic Offenders. HORS 206. London: Home Office.

Skogan, W. (1990) The Police And Public In England And Wales: A British Crime Survey Report. HORS No. 117. London: HMSO.

Southgate, P. And Mirrlees-Black, C. (1991) Traffic Policing In Changing Times.

HORS 124. London: HMSO. 
Sunday Times (2007) 'Sunday Times Offers Direct', Business Section, 15.07.07: 2. Svenson, O. (1981 'Are We All Less Risky And More Skilful Than Our Fellow Drivers?' Acta Psychologica, 47, 143-148.

The Times On-Line (2004) 'Beware Rise Of Big Brother State, Warns Data Watchdog’, 16.8.04. R. Ford.

http://www.timesonline.co.uk/tol/news/uk/article470264.ece

Tuffin, R., Morris, J. And Poole, A. (2006) An Evaluation Of The Impact Of The National Reassurance Policing Programme. HORS 296. London: Home Office. Waddington, P., Stenson, K. And Don (2004) 'In Proportion: Race, And Police Stop And Search'. British Journal Of Criminology, 44: 889-914

Wood, M. (2004) Perceptions And Experience Of Antisocial Behaviour: Findings From The 2003/2004 British Crime Survey. Home Office Online Report 49/04.

London: Home Office.

WHO (World Health Organisation) (2007) '10 Facts On Youth And Road Safety’. http://www.who.int/features/factfiles/youth_roadsafety/en/index.html

\footnotetext{
i 3,508 were killed on the roads and 853 were homicide victims in 2004- Compare Table 8.1 Transport Statistics GB (DfT 2004b) with Dodd et al (2004: 78).

${ }^{\text {ii }}$ A current alternative to achieving compliance at all times is via installation of in-vehicle devices that use GPS technology to alert drivers to upcoming speed cameras and their speed limits (e.g. Sunday Times, 2007). However, while these allow drivers to 'concentrate on the road ahead' (ibid) they only help drivers achieve compliance at speed camera sites and not in general.
} 